\title{
A PRELIMINARY REPORT ON THE GEOLOGY OF THE KOLI AREA
}

\author{
Tauno Pirrainen, Mikno Honkamo and Seppo Rossi
}

\begin{abstract}
Pirrainen, Tauno; Honkamo, Mrkko and Rossi Seppo 1974: A preliminary report on the geology of the Koli area. Bull. Geol. Soc. Finland 46, 161-166.

The bedrock of the Koli area originates from two separate orogenic cycles. Of these only the younger one, the Svecokarelian orogenic cycle, is dealt with in detail in this account. The sedimentary rock units of this cycle were deposited at the edges of the karelian geosyncl'nal basin. The origin of the sedimentary formations and that of the basic magmatism of the area is closely associated with the development of this basin which was characterized by the subsidence of its bottom, and by sudden releases of the thus generated strain field.
\end{abstract}

Tauno Piirainen and Seppo Rossi, Dept. of Geology, University of Oulu, SF-90100 Oulu 10, Finland. Mikko Honkamo, Geological Survey of Finland, SF-02150 Otaniemi, Finland.

\section{Introduction}

Extensive geological investigations were carried out in the north-eastern parts of the North Karelian schist belt at the end of the 1950's and in the beginning of the 1960's in connection with uranium ore explorations conducted by the Atomienergia, and Outokumpu companies. At that time the quartzite belt from Koli to Kaltimo was intensely explored. At the end of the 1960's, when prospecting for uranium began again, the examination of this quartzite belt was extended by Outokumpu Oy from Koli through Hattusaari village to Nunnanlahti, and from there further west to the »Höytiäinen arc». At this time prospecting was not limited to the quartzites alone, but parts of the basement complex in the east, and the phyllites in the west were also covered. Considerable amounts of geological data were gathered during this work, and these data serve as a base for the interpretation of the geology of the Koli area.

\section{Stratigraphy}

The stratigraphy of the Koli area is summarized in the map in Fig. 1. As can be seen, there are two main stratigraphic units: the basement complex, and the Svecokarelian formations. Both of these units have stratigraphical problems of their own.

The characteristic rock types of the basement complex are different gneisses. Of these, the granite, granodiorite, and trondhjemite gneisses are the main types. Within the gneisses there are erratic schist inclusions which at Koli, are represented by the Ipatti formation (Väyrynen 1933). The same formation continues to Hattu- 


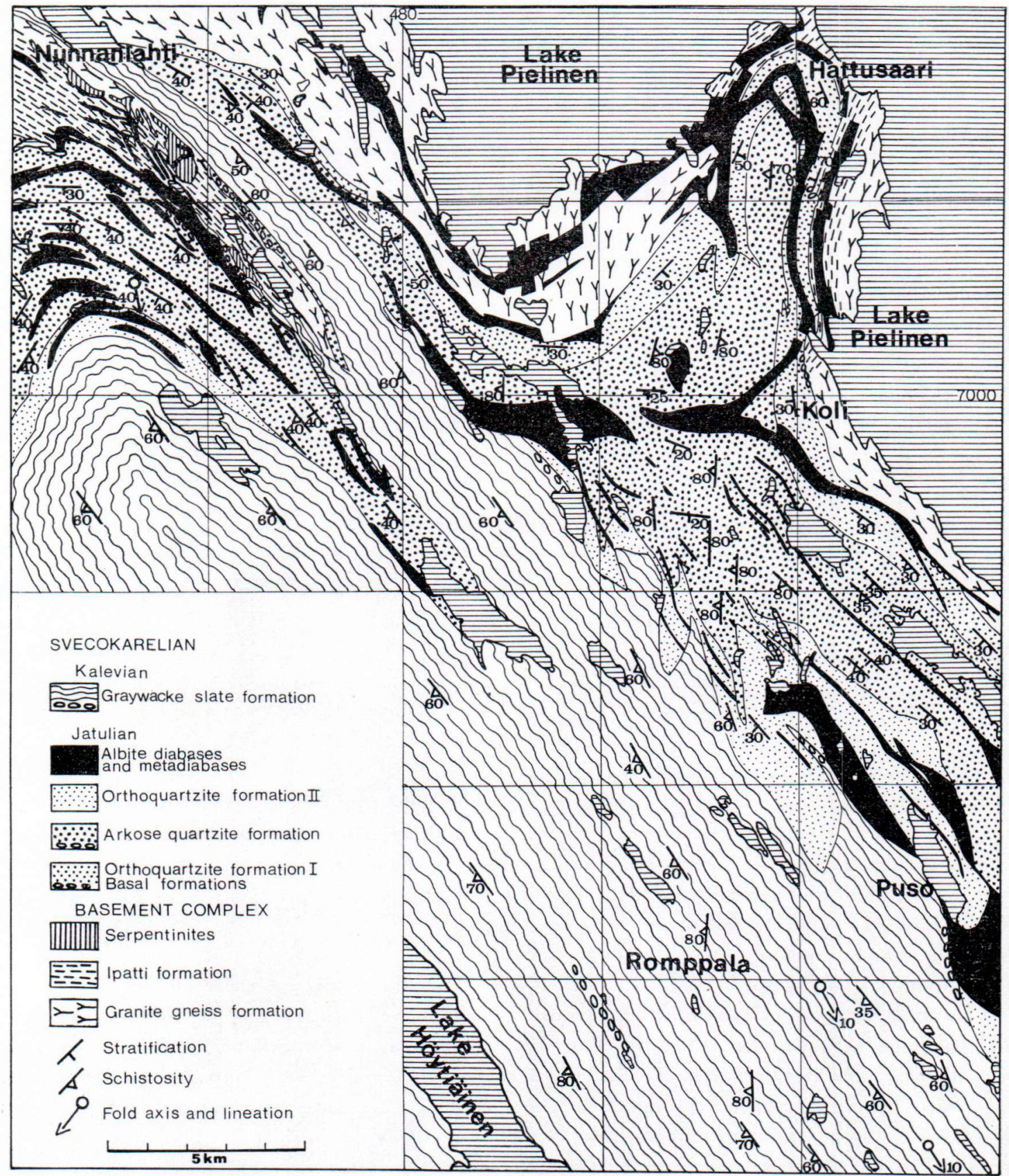

Fig. 1. Geological map of the Koli area.

saari, and appears again at Nunnanlahti. These schists are composed mainly of basic, intermediate, and acidic volcanics, and of sediments closely associated with volcanic activity. At some locations graywackes are found in which graded bedding is well preserved. The schists are cut by granites. Elsewhere they are replaced without any sharp contacts by different gneisses 
which, in a samples taken from the slope of the Koli hill, were determined to be 2.8 billion years old (Kouvo 1958).

In comparison with those of the basement complex the Svecokarelian metasediments are well preserved. They are sub-devided into the following formations, from the oldest to the youngest: basal, orthoquartzite I, arkose quartzite I, arkose quartzite, orthoquartzite II, and the graywacke schist formation. These sediments have been described by Gaál (1964), and by Piirainen (1968) for the area South of Koli. The first four formations can be correlated with the Jatulian formations, and the fifth with the Kalevian formations as designated by Väyrynen (1954). The Jatulian formations are cut by tholeiitic and spilitic hypabyssic intrusions (Piirainen 1969, Honkamo 1972) which are not encountered within the Kalevian formations in the area described here.

The above mentioned Jatulian quartzite formations continue without interruption from Koli through Hattusaari village to Nunnanlahti. From Nunnanlahti they extend further west as the »Höytiäinen arc», but not contiguously, being separated from the Koli-Nunnanlahti belt by a dislocation zone (Fig. 1). The orthoquartzite I formation is missing in the »Höytiäinen arc», and the Jatulian quartzites begin with the arkose quartzite formation just as they do in the south, on the northern side of the Jakokoski dome (Piirainen 1968). In the »Höytiäinen arc» the Jatulian quartzites begin with a conglomerate, the pebble material of which is composed mainly of gneisses, but also of meta diabases, albite diabases, and quartzites. These pebbles, however, are probably not Svecokarelian but most likely originate from the Pre-Svecokarelian Ipatti formation which, at Nunnanlahti, covers a wide area.

The absence of the orthoquartzite I formation from the »Höytiäinen arc» indicates the existence of a hiatus. Here the hiatus cuts the basement complex, but between Nunnanlahti and Koli it cuts only the orthoquartzite I formation. The orthoquartzite I formation could not have been very well consolidated before the development of the hiatus because no quartzite pebbles are found in the immediate vicinity of the hiatus level in the Koli-Nunnanlahti belt.

The arkose quartzite formation is cross bedded throughout. On the basis of this observation (Pasek 1971), and because of the continuity of the arkose quartzite formation to the »Höytiäinen arc», it is clear that the material has been transported from the east, northeast, and even northwest.

Another, more pronounced hiatus is found between the orthoquartzite II, and the graywacke schist formations. At the bottom of the graywacke schist formation there is a conglomerate, the pebble material of which, (e.g. at Puso), is composed of quartzites and metadiabases. North of Nunnanlahti the corresponding conglomerates are found in contact with the basement complex, and in addition to the above mentioned pebble materials they also contain rock types found in the basement complex. Some of the quartzite pebbles are schistose indicating that the Jatulian formations were deformed to some extent before the deposition of the Kalevian formations took place. All these data suggest that the hiatus between the Jatulian and the Kalevian formations covers a considerable area, but it does not seem to continue very far to the south where basic volcanics are found at the corresponding stratigraphical level (Nykänen 1971). In the Koli area these volcanics seem to have been eroded, and only their hypabyssic vents remain as dykes. No radiometric age determinations have been made on the basic magmatic rocks in the Koli area, but it is evident that they are of the same age as the basic volcanics to the south of the area. Here, these volcanics, have been dated by Kouvo at 2.15 billion years (oral communication).

The Kalevian basal conglomerates gradually change upwards into graywacke schists, the constituent minerals of which are quartz, plagio- 
clase, potassic feldspar, biotite and muscovite, with sulphides and graphite, and carbonates as accessory minerals. At some locations the amounts of these accessory minerals increase, and the resulting rocks can be called black schists, or limestones, respectively. The grain size in the graywacke schist formation is variable, e.g. at Romppala the coarsest fractions reach the grain size of a conglomerate. These conglomerates are situated in the middle of the Höytiäinen syncline thus representing the uppermost stratigraphical horizon.

\section{Structure}

In the basement complex a plastic phase of deformation is visible, followed by a separate rigid one. In connection with the plastic phase wide areas have been remobilized. The remobilized parts seem to build up fold structures which can be traced in the schists of the Ipatti formation. Acidic intrusive rocks which cut all the other rock types are also encountered. The rigid phase of deformation has developed in places into tectonic movements, which affect the whole formation thus generating fold structures of its own.

The structure of the Svecokarelian bedrock is far less complicated than that of the basement complex. The Svecokarelian formations have undergone only one phase of folding where the principal pressure has been from the southwest. During the deformation the quartzites and the basic dykes that cut them have together formed a competent bed, and the graywacke schist formation an incompetent one. Consequently, the quartzites and the basic dykes are weakly schistosed, and the strike and dip of the schistosity usually follow those of the bedding. In contrast, the graywacke schist formation is strongly foliated. The direction of schistosity is coincident with that of the axial plane.

The general strike of the bedding in the quartzite belt between Koli and Nunnanlahti is $\mathrm{N} 45^{\circ} \mathrm{W}$, and the $\operatorname{dip} 20^{\circ}-50^{\circ} \mathrm{SW}$. An exception to this rule is the Hattusaari trough, which is surrounded by steep angle bedding, and cut by $\mathrm{N}-\mathrm{S}$ striking vertical schistosity (Fig. 1). This is $\mathrm{S}_{2}$-schistosity which is diagonal to the direction of the principal pressure.

To the west of Nunnanlahti the quartzites form an arc (the »Höytiäinen arc», Fig. 1). Here also the bedding is coincident with the schistosity, and the strike follows that of the quartzite

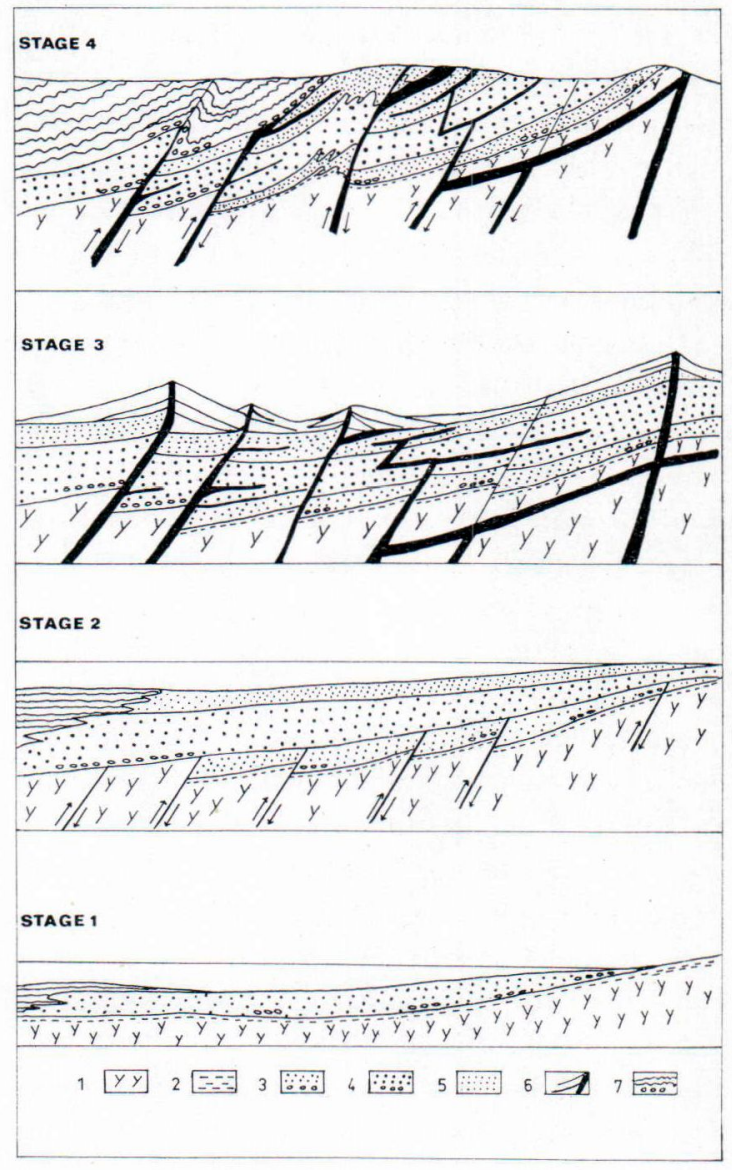

Fig. 1. Schematic illustration of the geological divelopement of the Koli area. Stage I: downwarping and deposition of the orthoquartzite I formation. Stage II: block movement I, erosion in places, downwarping and deposition of the arkose quartzite formation and orthoquartzite II formation. Stage III: block movement II and initial igneous activity. Stage IV: erosion, downwarping, deposition of graywacke schist formation and folding. 1 granite gneiss, 2 satrolithe, 3 orthoquartzite I, 4 arkose quartzite, 5 orthoquartzite II, 6 basic volcanics, dikes and sills, 7 graywacke schist. 
arc. Here the lineation is well developed in the $\mathrm{S}-\mathrm{SE} / 10^{\circ}-30^{\circ}$ direction. This indicates that the arc in question is a syncline the axis of which is slightly inclined to the southeast. The graywacke schists within the syncline have a schistosity at $\mathrm{N} 45^{\circ} \mathrm{W} / 40^{\circ}-80^{\circ} \mathrm{SW}$ which is also the direction of the axial plane, but is not coincident with the bedding. The direction of lineation is the same as that in the quartzites, $\mathrm{S}-\mathrm{SE} / 10^{\circ}-30^{\circ}$, and follows the direction of the micro folds. The $\mathrm{S}_{2}$-schistosity mentioned above, from the area south of the "Hattusaari arc," is also visible in places in the graywacke schists.

A shear zone, in the direction of the axial plane, separates the Höytiäinen syncline from the Koli-Nunnanlahti quartzites and graywacke schists. This shear zone was already active during the sedimentation, and along this zone, the southwestern block has risen relative to the northeastern one. The block movements have created a step like structure in the bedrock (Fig. 2). The same kind of structure, although on a considerably smaller scale, can also be noticed in a SW-NE direction.

\section{Geological evolution}

The geological evolution of the Koli area is connected with the development of two orogenic cycles. There is no generally accepted name for the older one. The formations of this nameless orogenic cycle are visible in the basement complex. Its geological evolution is not considered further in this account other than in stating that the basement complex displays an eugeosynclinal milieu with graywackes and volcanics. A totally different milieu can be noticed in the younger, the Svecokarelian orogenic cycle. Here the regional remobilization is missing, and the sedimentary series are relatively well preserved. Moreover the geological evolution can be easily tracked.

The sedimentary series of the Svecokarelian orogenic cycle were generated under a north- easterly directed pressure. The orthoquartzite I formation was deposited during the slow subsidence of the bottom of the sedimentary basin, as the result of the reworking of the sediments of the basal formation. The strain field generated by the subsidence of the bottom was released by block movements. The blocks on the basin side rose relative to both the blocks on the foreland side, and to those in the culmination area. This resulted in the erosion of the raised blocks, and in the acceleration of the speed of sedimentation in the basin (Fig. 2). Thus, as the bottom continued to sink, instead of the pure quartz sands the sedimentation of arkosic sands commenced, and the arkose quartzite formation was deposited. However, circumstances comparable with the initial stage of development were gradually resumed, and pure quartz sands were again deposited to form the orthoquartzite II formation. The strain field generated by the subsidence of the bottom was once again released by block movements in the above mentioned directions, and these movements led to basic volcanic activity. Later on these volcanics were eroded, and only their vents remain as hypabyssic basic dykes. After this, the bottom sank rapidly, and the sedimentary basin was covered by deep water which created conditions suitable for the deposition of the graywacke schist formation. During the sedimentation of this formation turbidity currents were noticeable. The pebble material of the graywacke conglomerates, and the mineral composition of the graywackes themselves indicate that this material originates from the basement complex which, on the basis of the observed continuity of the sedimentary beds, was exposed in the foreland area in the northeast as well as in the culmination area in the northwest. As the bottom continued to subside the sedimentary formations were deformed, the quartzites and the cutting basic dykes forming a competent unit, and the graywacke schist formation forming an incompetent one. 


\section{REFERENCES}

GAÁL, G. (1964) Jatul und karelische Molasse im SKoligebiet in Nordkarelien und ihre Beziehungen zum Gebirgsbau des präkambrischen Orogens. Bull. Comm. Géol. Finlande 213.

Honkamo, M. (1972) Kolin-Juuan alueen ultramafiset kivilajit. Master's thesis. Manuscript in the archives of the Department of Geology, University of Oulu, Finland.

Kouvo, O. (1958) Radioactive Age of some Finnish Pre-Cambrian Minerals. Bull. Comm. Géol. Finlande 182.

Nykänen, O. (1971) On the Karelides in the Tohmajärvi area, eastern Finland. Bull. Geol. Soc. Finland 43: 93-108.
PASEK, J. (1971) Report about the research in precambrian sedimentary rocks on the Karelides in the Koli-area. The archives of Outokumpu Co, Finland.

Pitrainen, T. (1968) Die Petrologie und die Uranlagerstätten des Koli-Kaltimogebiets im finnischen Nordkarelien. Bull. Comm. Géol. Finlande 237.

-(1969) Initialer Magmatismus und seine Erzbildung in der Beleuchtung des Koli-Kaltimogebiets. Bull. Geol. Soc. Finland 41.

VÄYRYNEN, H. (1933) Über die Stratigraphie der karelischen Formationen. C. R. Soc. Géol. Finlande 6. Bull. Comm. Géol. Finlande 101.

- (1954) Suomen kallioperä. Helsinki.

Manuscript received, March 18, 1974. 